AWEJ for Translation \& Literary Studies, Volume3, Number1. February 2019

DOI: http://dx.doi.org/10.24093/awejtls/vol3no1.13

Pp.157-177

\title{
Investigating Cohesive Devices in Wordsworth Poetry
}

\author{
Mohamed Jabraddar Mahil Abd Allah \\ Department of Languages and Translation \\ Faculty of Education and Arts \\ Northern Border University, Arar, Saudi Arabia
}

\begin{abstract}
This study has attempted to investigate the use of cohesive devices in Wordsworth poetry. It has aimed to understand the role of stylistics analysis in shaping the meanings of literary texts. In addition to explain how cohesion can contribute to interpreting and understanding poetry. The significant of the study is based on the fact that it contributes to the understanding of how linguistic and stylistic analysis of a text can be used, extensively, to clarify features and meanings in texts. Nine poems were selected to represent Wordsworth poetry. The poems were selected randomly. Cohesive devices were identified in the poems and analyzed using the content analysis technique. They were analyzed quantitatively. The analysis revealed a number of interesting results, namely: All types of cohesive devices were used in the poems selected for the purpose of the study (reference, substitution, ellipsis, conjunction and lexical cohesion). There were some variations in the use of some devices; in that certain devices were used at a very high rate of frequency compared to others. The main function of the use of cohesive devices within the poems was to help the poet express romantic values. Based on the results obtained, the study suggests the following: First, it would be interesting, for further studies to conduct more studies on the coherence of English literary discourse. Second, it is worth to investigate cohesive devices of the sociolinguistic aspects within poetry, as poetry is an important area whose genre contains impressive socio-cultural meaning.
\end{abstract}

Keywords: cohesive devices, cohesion, poetry studies, Romantic poetry, Wordsworth

Cites as: Abd Allah, M.J. M. (2019). Investigating Cohesive Devices in Wordsworth Poetry. Arab World English Journal for Translation \& Literary Studies, 3 (1) 157-177.

DOI: http://dx.doi.org/10.24093/awejtls/vol3no1.13 